\title{
PERBANDINGAN NILAI PRAKTIKUM HISTOLOGI BERDASARKAN TINGKAT KECEMASAN PADA MAHASISWA KEDOKTERAN
}

\author{
Arlends Chris ${ }^{1}$, Sari Mariyati Dewi ${ }^{2}$, Twidy $\operatorname{Tarcisia}^{3}$ dan Willy Tasdin ${ }^{4}$ \\ ${ }^{1,2,3}$ Fakultas Kedokteran Bagian Histologi, Universitas Tarumanagara Jakarta \\ arlendsc@fk.untar.ac.id; sarim@fk.untar.ac.id; twidyt@fk.untar.ac.id \\ ${ }^{4}$ Fakultas Psikologi, Universitas Tarumanagara Jakarta \\ willytasdin@gmail.com
}

\begin{abstract}
ABSTRAK
Dalam kehidupan sehari-hari, mahasiswa pasti akan mengalami kecemasan dalam berbagai situasi lingkungan akademik. Mahasiswa kedokteran khususnya, memiliki kecenderungan tingkat kecemasan yang lebih tinggi dibandingkan dengan mahasiswa lainnya dalam rentang umur sebaya. Tingkat kecemasan ini dapat memberikan efek negatif bila tidak tertangani dengan baik, terutama terhadap performa akademik mahasiswa. Tujuan penelitian ini adalah mengetahui perbandingan nilai praktikum Histologi mahasiswa berdasarkan tingkat kecemasan mahasiswa. Diharapkan, hasil penelitian ini dapat digunakan untuk mengurangi tingkat kecemasan mahasiswa kedokteran dalam menjalani pendidikannya sebagai calon dokter. Metode yang digunakan adalah desain kuantitatif dengan membandingkan tingkat kecemasan terhadap hasil ujian mahasiswa. Instrumen yang digunakan adalah kuesioner Beck Anxiety Inventory (BAI) dan tes akademik. Responden terdiri dari 88 orang mahasiswa yang dipilih dengan cara purposive non-random sampling. Data yang didapatkan dianalisis dengan menggunakan perangkat lunak SPSS versi 22 menggunakan one-way ANOVA. Hasil penelitian menunjukkan, bahwa rata-rata nilai ujian praktikum Histologi pada mahasiswa dengan tingkat kecemasan rendah (mean $=80.95 \pm 8.78$ ) lebih tinggi daripada kelompok mahasiswa dengan tingkat kecemasan sedang (mean=72.87 \pm 12.03$)$ dan tinggi $($ mean=77.00 \pm 10.81$)$. Hasil uji homogenitas variansi dengan Levene Statistic adalah 0.651 dengan nilai kemaknaan sebesar 0.524 $(p>0.05)$ yang berarti variansi dari ketiga ujian sama. Hasil uji statistik dengan one-way ANOVA menunjukkan nilai $F$ hitung adalah 5.362 dengan nilai kemaknaan sebesar $0.006(p<0.05)$ yang berarti terdapat perbedaan nilai ujian praktikum histologi mahasiswa terhadap tingkat kecemasan. Kesimpulan hasil penelitian menunjukkan bahwa perbandingan rata-rata nilai ujian praktikum Histologi lebih tinggi pada mahasiswa dengan tingkat kecemasan rendah dibandingkan dengan mahasiswa yang memiliki tingkat kecemasan sedang dan tinggi.
\end{abstract}

Kata kunci: pendidikan kedokteran, histologi, kesehatan mental, kecemasan, BAI

\section{PENDAHULUAN}

Tujuan dari pendidikan kedokteran adalah menghasilkan dokter yang berpengetahuan, kompeten dan berpraktik secara profesional untuk melayani kebutuhan masyarakat, meningkatkan pengetahuan dan keilmuan dalam bidang kedokteran dan mempromosikan kesehatan kepada masyarakat. Untuk mencapai tujuan tersebut, mahasiswa perlu menempuh pendidikan dokter selama 5 tahun, yang terdiri dari pendidikan preklinik dan klinik. Setelah menjalani pendidikan dokter, mereka juga perlu mengikuti uji kompetensi dokter yang merupakan standar minimal yang harus dicapai (Konsil Kedokteran Indonesia [KKI], 2015).

Untuk menghadapi persiapan dalam upaya mencapai standar yang ditetapkan, pendidikan kedokteran berusaha mengantisipasi dengan berbagai cara pembelajaran. Sehingga, lamanya masa pendidikan dan padatnya jadwal kegiatan menimbulkan tekanan bagi mahasiswa. Berbagai tekanan dan beban tersebut kadang memberikan efek negatif pada kesehatan mental mahasiswa (Dyrbye, Thomas, \& Shanafelt, 2006). Beberapa faktor yang menjadi penyebabnya adalah tekanan akademik, hambatan untuk mencapai tujuan, perubahan lingkungan dan tantangan hidup seperti perpindahan dari sekolah ke universitas, dan juga perubahan peran dari siswa menjadi mahasiswa yang berpengetahuan (Saravanan \& Wilks, 2014). 
Mahasiswa kedokteran memiliki kecenderungan tingkat kecemasan yang lebih tinggi dibandingkan dengan mahasiswa lainnya dalam kisaran umur yang sama (Saravanan et al., 2014; Wild, Scholz, Ropohl, Paulsen, \& Burger, 2014). Prevalensi angka kecemasan diantara mahasiswa kedokteran pada beberapa universitas negeri di Pakistan, Malaysia, Yunani, dan Beirut sebesar $43.7 \%$ hingga $69 \%$. Sedangkan pada mahasiswa kedokteran di universitas swasta sebesar 29.4\% hingga 60\% (Saravanan et al., 2014).

Berdasarkan data tersebut, penting untuk mengetahui tingkat kecemasan mahasiswa kedokteran terhadap hasil belajar. Peneliti memilih hasil belajar berupa nilai ujian praktikum Histologi yang merupakan bagian dari ilmu Anatomi. Anatomi merupakan bidang ilmu pertama dan tersulit pada pendidikan kedokteran (Jayanthi, Sajna, \& Benjamin, 2014). Pada ujian Histologi, mahasiswa diminta untuk mendiagnosis suatu sediaan/jaringan/sel dengan waktu yang terbatas, sekitar 30 sampai 60 detik untuk satu soal. Adanya batasan waktu tersebut, peneliti berasumsi bahwa kecemasan mahasiswa akan meningkat selama mengerjakan ujian praktikum. Beberapa penelitian juga menyatakan bahwa terdapat penurunan performa akademis atau perbedaan hasil ujian pada mahasiswa yang mengalami kecemasan oleh berbagai stressor yang ada di lingkungan belajar (Huberty, 2012; Murphy, Gray, Sterling, Reeves, \& DuCette, 2009).

Tujuan penelitian ini adalah untuk membandingkan nilai ujian praktikum Histologi berdasarkan tingkat kecemasan pada mahasiswa fakultas kedokteran. Manfaat dari hasil penelitian ini diharapkan dapat berguna untuk mengambil tindakan pencegahan terhadap mahasiswa yang rentan mengalami kecemasan tingkat sedang dan tinggi. Selain itu, juga diharapkan dapat bermanfaat bagi pengembangan bahan dan strategi pembelajaran dan pelaksanaan ujian di bagian Histologi. Sehingga, stresor yang menyebabkan kecemasan berlebihan terhadap mahasiswa dapat dikurangi. Diharapkan nantinya pembelajaran menjadi lebih efektif, efisien dan menyenangkan. Kemudian, pemahaman penyelenggara pendidikan terhadap kesehatan mental mahasiswa merupakan hal penting dalam membuat kebijakan tentang kesehatan mental dan pelayanan mental pada kelompok mahasiswa yang rentan. Lebih lanjut lagi, sebagai calon dokter yang nantinya bekerja sebagai profesional kesehatan, penyelenggaran pendidikan perlu mengetahui sejak awal masalah-masalah yang terjadi untuk mengantisipasi dan membantu mereka mencapai tujuan pendidikan tersebut.

\section{METODE}

\section{Subjek Penelitian}

Pada penelitian potong lintang ini, subjek penelitian terdiri dari 88 orang mahasiswa fakultas kedokteran yang terdaftar pada kelas praktikum Histologi Blok Urogenital. Subjek merupakan mahasiswa semester 6 dengan rentang usia 19-21 tahun.

\section{Instrumen Penelitian}

Instrumen penelitian terdiri dari 2 alat ukur yaitu berupa non test atau Beck Anxiety Inventory (BAI) dan test atau soal ujian praktikum Histologi. Instrumen pertama yang digunakan adalah kuesioner BAI yang disusun oleh Aaron T. Beck dan Robert A. Steer. Kuesioner umumnya digunakan untuk responden dengan usia lebih dari 18 tahun. Kuesioner BAI terdiri dari 21 butir pernyataan mengenai kecemasan dengan skala 0-3. Skor 0 untuk "Not at all", skor 1 untuk "Mildly but it didn't bother me much", skor 2 untuk "Moderately-it was not pleasant at a time", dan skor 3 untuk "Severely-it bothered me a lot". Hasilnya dikelompokan menjadi 3 kategori yaitu skor antara 0-21 adalah low anxiety, skor antara 22-35 adalah moderate anxiety dan skor lebih dari 36 adalah potentially concerning levels of anxiety. Contoh butir pernyataan instrumen BAI, berdasarkan gejala umum kecemasan adalah "Numbness or tingling", "Feeling hot", dan 
seterusnya. Uji reliabilitas internal Cronbach's alpha sebesar 0.92 dan reliabilitas test-retest sebesar 0.75 (Beck, Epstein, Brown, \& Steer, 1988; Muntingh et al., 2011). Instrumen kedua adalah soal ujian praktikum Histologi yang disusun oleh tim dosen bagian Histologi yang terdiri dari 3 orang dosen. Jumlah soal ujian sebanyak 40 soal berupa gambar sediaan/jaringan/sel mikroanatomi dengan 4 pilihan jawaban.

\section{Prosedur Penelitian}

Prosedur penelitian dilakukan dengan memberikan penjelasan dan pengarahan kepada mahasiswa setelah mereka selesai ujian praktikum Histologi. Penjelasan berupa tujuan penelitian dan juga permintaan ijin kesediaan dan keikutsertaan dalam penelitian dengan informed consent. Setelah diberikan penjelasan yang cukup, mahasiswa diminta mengerjakan kuesioner BAI selama 10-15 menit. Data yang didapatkan kemudian diolah menggunakan perangkat lunak statistik IBM SPSS versi 22, menggunakan one-way ANOVA.

\section{HASIL DAN PEMBAHASAN}

Sebanyak 88 orang responden berpartisipasi dalam penelitian ini. Responden merupakan mahasiswa preklinik fakultas kedokteran yang mengikuti pembelajaran di laboratorium Histologi dalam blok urogenital. Mayoritas responden adalah perempuan $(72.70 \%, n=64)$. Jumlah responden laki-laki sebanyak 24 orang $(27.30 \%)$. Umur responden antara 19-21 tahun dan belum menikah. Status tempat tinggal mahasiswa, umumnya adalah kost sebanyak 41 orang (46.60\%), mahasiswa yang tinggal di rumah sendiri sebanyak 40 orang $(45.50 \%)$ dan sisanya kontrak atau tinggal bersama saudara sebanyak 7 orang $(7.9 \%)$. Berdasarkan kesediaan waktu belajar mandiri mahasiswa, didapatkan sebanyak 42 orang $(47.73 \%)$ memiliki waktu belajar selama 5-10 jam per minggu, 31 orang $(35.23 \%)$ memiliki waktu belajar kurang dari 5 jam per minggu dan 15 orang $(17.04 \%)$ memiliki waktu belajar lebih dari 10 jam per minggu. Gambaran data mahasiswa menurut nilai hasil ujian praktikum Histologi didapatkan terbanyak adalah nilai A (lebih dari 80) sebanyak 52 orang (59.10\%), nilai B (70-79) sebanyak 23 orang (26.10\%), nilai C (56-69) sebanyak 10 orang (11.40\%), dan yang tidak lulus atau mendapatkan nilai D atau E sebanyak 3 orang (3.4\%). Berdasarkan hasil kuesioner BAI, didapatkan data mahasiswa yang mengalami kecemasan tingkat rendah sebanyak 63 orang (71.59\%), kecemasan tingkat sedang sebanyak 20 orang $(22.72 \%)$ dan kecemasan tingkat tinggi sebanyak 5 orang $(5.69 \%)$. Kelima mahasiswa yang mengalami kecemasan tinggi tersebut perlu mendapatkan perhatian lanjut. Distribusi data mahasiswa berdasarkan jenis kelamin, tempat tinggal, waktu belajar, nilai ujian praktikum dan tingkat kecemasan mahasiswa dapat dilihat pada Tabel 1.

Tabel 1

Distribusi Data Mahasiswa Berdasarkan Jenis Kelamin, Tempat Tinggal, Waktu Belajar, Nilai Ujian Praktikum dan Tingkat Kecemasan Mahasiswa (n=88)

\begin{tabular}{ll}
\hline Variabel & Jumlah (\%) \\
\hline Jenis Kelamin & \\
\hline Laki-laki & $24(27.30)$ \\
\hline Perempuan & $64(72.70)$ \\
\hline Tempat Tinggal & \\
\hline
\end{tabular}




\begin{tabular}{lc}
\hline Kost & $41(46.60)$ \\
\hline Rumah sendiri & $40(45.50)$ \\
\hline Rumah kontrak & $7(7.9)$ \\
\hline Waktu Belajar (per minggu) & $31(35.23)$ \\
\hline$<5$ jam & $42(47.73)$ \\
\hline $5-10$ jam & $15(17.04)$ \\
\hline$>10$ jam & \\
\hline Nilai Ujian Praktikum & $52(59.10)$ \\
\hline A $>>80)$ & $23(26.10)$ \\
\hline B (70-79) & $10(11.40)$ \\
\hline C $(56-69)$ & $2(2.3)$ \\
\hline D $(45-55)$ & $1(1.1)$ \\
\hline E $(<45)$ & $63(71.59)$ \\
\hline Tingkat Kecemasan (BAI) & $20(22.72)$ \\
\hline Rendah & $5(5.69)$ \\
\hline Sedang & \\
\hline Tinggi & \\
\hline Catan The Beck Anxety & \\
\hline
\end{tabular}

Catatan. The Beck Anxiety Inventory (BAI) berasal dari sumber Beck et al. (1988).

Pada Tabel 2, dapat dilihat rata-rata skor tingkat kecemasan mahasiswa dari hasil pengolahan kuesioner BAI. Hasil skor kecemasan terbagi menjadi 3 kategori yaitu: mahasiswa dengan tingkat kecemasan rendah, tingkat kecemasan sedang dan tingkat kecemasan tinggi. Analisis one-way ANOVA digunakan untuk membandingkan ketiga kelompok kategori tersebut. Dari hasil analisis didapatkan, rata-rata nilai ujian praktikum Histologi pada mahasiswa dengan tingkat kecemasan rendah adalah 80.95 dengan standar deviasi 8.78. Pada mahasiswa dengan tingkat kecemasan sedang, rata-rata nilai ujian praktikum Histologi adalah 72.87 dengan standar deviasi 12.03. Sedangkan pada kelompok mahasiswa dengan tingkat kecemasan tinggi, rata-rata nilai ujian praktikum Histologi adalah 77.00 dengan standar deviasi 10.81 .

Hasil uji homogenitas variansi dengan Levene Statistic adalah 0.651 dengan nilai kemaknaan sebesar 0.524 ( $\mathrm{p}>0.05$ ), yang berarti bahwa $\mathrm{H}_{0}$ diterima atau variansi dari ketiga nilai ujian sama sehingga uji ANOVA dengan menggunakan nilai $\mathrm{F}$ dapat dilakukan. Hasil uji statistik ANOVA menunjukkan bahwa nilai $\mathrm{F}$ hitung adalah 5.362 dengan signifikansi sebesar $0.006(<0.05)$ yang dapat disimpulkan bahwa terdapat perbedaan nilai ujian praktikum Histologi diantara ketiga kategori tingkat kecemasan. Analisis lebih lanjut membuktikan bahwa kelompok yang berhubungan bermakna adalah tingkat kecemasan mahasiswa yang rendah dengan tingkat kecemasan mahasiswa yang sedang, dan tingkat kecemasan mahasiswa yang rendah dengan tingkat kecemasan mahasiswa yang tinggi. 
Tabel 2

Distribusi Rata-rata Nilai Ujian Praktikum Histologi Menurut Tingkat Kecemasan Mahasiswa

\begin{tabular}{lcccc}
\hline & Mean & SD & 95\% CI & P value \\
\hline Kecemasan & & & & \\
\hline Rendah & 80.95 & 8.78 & $78.74-83.16$ & $0.006^{*}$ \\
\hline Sedang & 72.87 & 12.03 & $67.24-78.50$ & \\
\hline Tinggi & 77.00 & 10.81 & $63.57-90.42$ & \\
\hline
\end{tabular}

Catatan $. \mathrm{n}=88 . \mathrm{SD}=$ standard deviation; $\mathrm{CI}=$ confidence interval.

$* p<.05$.

Secara teori terdapat 3 faktor yang dapat menyebabkan kecemasan yaitu: genetik dan temperamen, sensitifitas kecemasan dan riwayat penyakit terdahulu serta riwayat kekerasan fisik yang terjadi sebelumnya (Craske \& Barlow, 2008). Sedangkan berdasarkan data rentang hasil ujian praktikum Histologi, didapatkan bahwa mahasiswa dengan tingkat kecemasan yang rendah mendapatkan hasil ujian yang lebih tinggi daripada kelompok mahasiswa dengan tingkat kecemasan sedang dan tinggi. Hal ini sesuai dengan beberapa penelitian lainnya bahwa kecemasan dalam bidang akademis dapat semakin merugikan seiring berjalannya waktu. Semakin menurunnya performa akademis, maka tingkat kecemasan juga akan semakin meningkat (Huberty, 2009).

Untuk mengurangi tingkat kecemasan, salah satu faktor dasar yang dapat membantu adalah keluarga dan juga pendidik (Dobson, 2012). Oleh karena itu, kedekatan dan dukungan dari keluarga juga sangat diperlukan. Pendidik pun memiliki peranan penting dalam memberikan persiapan kepada mahasiswa dalam menghadapi ujian. Beberapa pendekatan dan terapi dapat diterapkan untuk membantu mengurangi kecemasan, dan juga dengan kombinasi pengobatan medis dapat membantu menurunkan perasaan dan gejala kecemasan. Selain itu, Cognitive Behavioral Therapy (CBT) juga dapat membantu mahasiswa menemukan cara coping yang baik dan belajar metode-metode baru untuk menghadapi situasi yang membuat mereka cemas (Torpy, Burke, \& Golub, 2011). Teknik relaksasi seperti meditasi, yoga dan olahraga, juga dapat meningkatkan mood dan kesehatan secara keseluruhan (Wild et al., 2014). Berbagai terapi lainnya juga mungkin masih banyak, prinsipnya adalah menyesuaikan pendekatan dan terapi dengan kebutuhan individu secara spesifik (Torpy et al., 2011).

\section{KESIMPULAN DAN SARAN}

Kesimpulan penelitian didapatkan, bahwa perbandingan rata-rata nilai ujian praktikum Histologi lebih tinggi pada kelompok mahasiswa dengan tingkat kecemasan rendah, dibandingkan dengan mahasiswa yang memiliki tingkat kecemasan sedang dan tinggi. Saran untuk penelitian lanjutan adalah mengumpulkan dan menentukan faktor-faktor stresor di lingkungan fakultas kedokteran. Sehingga, penelitian tersebut dapat bermanfaat untuk menurunkan tingkat kecemasan dalam lingkungan akademik dan juga dapat dilakukan tindak lanjut bila terdapat faktor lain yang tidak dapat ditangani dalam lingkungan akademik. Selain itu perlu diteliti lebih lanjut mengenai komorbiditas atau hadirnya simtom-simtom depresi yang terdapat pada mahasiswa yang mengalami kecemasan. Selain kecemasan, ada beberapa faktor psikologis yang juga memengaruhi prestasi akademik seseorang seperti self-efficacy, konsep diri, dan sifat perfeksionis. 


\section{REFERENSI}

Beck, A. T., Epstein, N., Brown, G., \& Steer, R. A. (1988). An inventory measuring clinical anxiety: Psychometric properties. Journal of Consulting and Clinical Psychology, 56(6), 893-897. doi: 10.1037/0022-006X.56.6.893

Craske, M. G., \& Barlow, D. H. (2008). Panic disorder and agoraphobia. D. H. Barlow (Eds), Clinical handbook of psychological disorder: A step by-step treatment manual (4th ed.), (p.5). New York: NY: Guilford Press.

Dobson, C. (2012). Effects of academic anxiety on the performance of students with and without learning disabilities and how students can cope with anxiety at school. Diunduh dari https://www.nmu.edu/

Dyrbye, L. N., Thomas, M. R., \& Shanafelt, T. D. (2006). Systematic review of depression, anxiety, and other indicators of psychological distress among U.S. and Canadian medical students. Journal of the Association of American Medical Colleges, 81(4), 354-373.

Huberty, T. J. (2009). Test and performance anxiety. Principal Leadership, 10, 12-16. Retrieved from http://www.nasponline.org/

Jayanthi, A., Sajna, M. V., \& Benjamin, B. (2014). Students' perception of teching learning method in dissection and histology lab. IOSR Journal of Dental and Medical Sciences (IOSR-JDMS), 13(11), 24-28. e-ISSN: 2279-0853.

Konsil Kedokteran Indonesia. (2012). Standar kompetensi dokter Indonesia. Jakarta: Konsil Kedokteran Indonesia.

Muntingh, A. D., van der Feltz-Cornelis, C. M., van Marwijk, H. W., Spinhoven, P., Penninx, B. W., \& van Balkom, A. J. (2011). Is the beck anxiety inventory a good tool to assess the severity of anxiety? A primary care study in The Netherland study of depression and anxiety (NESDA). BMC Family Practice, 12, 1 -6. doi: 10.1186/1471-2296-12-66

Murphy, R. J., Gray, S. A., Sterling, G., Reeves, K., \& DuCette, J. (2009). A comparative study of professional student stress. Journal of Dental Education, March 1, 2009, 73(3), 328337. Retrieved from http://www.jdentaled.org/content/73/3/328.full

Saravanan, C., \& Wilks, R. (2014). Medical student's experience of and reaction to stress: The role of depression and anxiety. The Scientific World Journal, 2014, 1 - 8. doi: $10.1155 / 2014 / 737382$

Torpy, J. M., Burke, A. E. \& Golub, R. M. (2011). Generalized anxiety disorder. JAMA, 305(5):522. doi: 10.1001/jama.305.5.522

Wild, K., Scholz, M. Ropohl, A., Paulsen, F., \& Burger, P. H. M. (2014). Strategies against burnout and anxiety in medical education - Implementation and evaluation of a new course on relaxation technique (relacs) for medical students. Plos ONE, 9(12): e114967. doi:10.1371/journal.pone.0114967 